\section{NEW EPS}

\section{ASSOCIATE MEMBERS}

Bruker Analytische

Messtechnik GmbH

Am Silberstreifen

D-7512 Rheinstetten 4

Dr. Wilhelm Heinrich Heraeus

und Else Heraeus - Stiftung

Heraeusstrasse 12-14

Postfach 1553

D-6450 Hanau 1

\section{QE Division}

Immediately following the 7th EPS General Conference, the Quantum Electronics Division is holding a satellite meeting on "Laser Induced Processes in Matter". This will take place in Helsinki from 15-17 August 1987.

Members of the Division should also note that a business session will be held on that occasion. This has been fixed for Saturday, 15 August at $16 \mathrm{hoO}$.

\section{Physical Society of Japan Sectional Meetings}

Members of EPS are invited to present their original papers at the PSJ's sectional meetings which take place at the end of September 1987. Deadline for proposals is 30 June.

At the 'first' of these from 30 Sept.3 October held at Utsunomiya University, Utsunomiya-shi, Tochigi-ken, the topics will concern elementary particle theory and experiment, nuclear theory and experiment and cosmic rays.

The 'second', running from 26-29 September at Tohoku University, Sendai-shi, Miyagi-ken, covers practically all the other fields of physics.

Further information from

The Physical Society of Japan

Room 211, Kikai-Shinko Building

3-5-8 Shiba-Koen, Minato-Ku

Tokyo 105, Japan

\section{University of Aarhus}

\section{Professorship of Physics}

At the Institute of Physics, University of Aarhus, provided that sufficient funding is made available, a chair of physics $w$ ill be vacant as from $1 \mathrm{March}, 1988$.

The professor to occupy the chair is expected to conduct research and teaching in theoretical solid state physics. Applicants whose field of research can strengthen established theoretical and experimental research activities at the Institute will be given preference.

Applications should include copies (in triplicate) of the published papers which the applicant wishes to have considered by the Selection Committee, a list of these, and a statement of the applicant's future research plans. In addition, information on the applicant's experience in teaching and administration is requested, together with a list of positions occupied, and other relevant material.

All applicants will receive a copy in full of the evaluation of their application by the Selection Committee.

Further information, e.g. concerning salary, research activities, teaching duties, and staff, may be obtained from the Chairman of the Institute:

Lektor, Dr. Phil. Bent Fastrup,

Det fysiske Institut, Ny Munkegade,

DK - 8000 Aarhus C, Denmark

Telephone: (6) 128899 .

Applications should be addressed to the Queen of Denmark and sent to

THE UNIVERSITY OF AARHUS,

Ndr. Ringgade 1, DK - 8000 Aarhus C, Denmark

and marked 211-19.

Deadline for the receipt of all applications material is 1 September, 1987, at twelve o'clock.
EPS Divisions, Sections and Group

Astronomy and Astrophysics Division Solar Physics Section

Atomic and Molecular Physics Division

Atomic Spectroscopy Section

Chemical Physics

Electronic and Atomic Collisions

Molecular Physics

Computational Physics Group

Condensed Matter Division

Liquids Section

Low Temperature Physics Section

Macromolecular Physics

Magnetism

Metal Physics

Semiconductors and Insulators

Surfaces and interfaces

High Energy \& Particle Physics Division

Interdiv. Group on Exptl. Phys. Control Systems

Interdiv. Group on Physics for Development

Nuclear Physics Division

Optics Division

Plasma Physics Division

Quantum Electronics Division
Europhysics News is the official journal of the European Physical Society which comprises 29 National Societies, Academies and Group, about 4000 Individual Members and 70 Associate Members. Governing bodies of EPS are the General Meeting, Council and an elected Executive Committee responsible for detailed policy. EPS promotes the collaboration of physicists policy. EPS promotes the collaboration of physicists
throughout Europe, organising and harmonising conferences and publications, improving physics education, encouraging physics applications, awarding scholarships to sponsored schools in Erice. EPS publishes in addition to Europhys. News, Europhysics Letters (in partnership with national societies), European Journal partnership with national societies), European Journal of Physics (in partnership with The UK Inst. of Phys.), and European Conference Abstracts. individual Members receive Europhys. News free of charge (price to insts.: Sw.Fr. 90.-/a), Europhys. Lett. at Sw.Fr. 70.-/a (insts. 595.-), rebates on many other publications and on conference fees. Annual EPS membership fee for In dividual Members belonging to an EPS member society is: Sw.Fr. 44.-; independent members: Sw.Fr. 132.-; members of a Collaborating Society: Sw.Fr. 55.-

\section{Editor: E.N. Shaw}

Editorial Board:

A. Baratoff, F. James, M. Lehmann,

M. Mayor, J. Muller, M. Siegrist

Editorial and Advertising Office at the EPS Secretariat

Address: EUROPEAN PHYSICAL SOCIETY

P.O. Box 69

CH-1213 Petit-Lancy 2

Switzerland

Telephone: Geneva (22) 931130

Telex : 428024 eps ch

Cables: europhys genève

Printed by: Pfirter frères sa CH-1213 Petit-Lancy/Switzerland 